\title{
Quality Assessment of Sweetmeat (Rosogolla) Of Dhaka and Tangail Region of Bangladesh
}

\author{
U. K. Prodhan ${ }^{1}$, Md. Jahangir Alam ${ }^{1 *}$, Abida Sultana ${ }^{1}$, Md. Harun-Ar Rashid ${ }^{1}$, \\ Tumpa Das ${ }^{1}$, Nargis Akter ${ }^{1}$, Mohammad Mahfuzur Rahman ${ }^{2}$ \\ Department of Food Technology and Nutritional Science, Mawlana Bhashani Science and Technology \\ University, Tangail-1902, Bangladesh \\ Senior Scientific Officer, Food Safety lab, Institute of Food Science and Technology, Bangladesh Council \\ for Scientific and Industrial Research, Dhaka-1201
}

\begin{abstract}
An experimental study was design to assess the nutritional quality of the Rosogolla available in Dhaka and Tangail region of Bangladesh. Sweetmeats were collected from a branded shop in Mirpur road and non-branded Rosogolla in Dhaka city area and a branded shop in pachani bazar and non-branded Rosogolla available at old bus-stand of Tangail district area. Quality of the Rosogolla was evaluated by chemical, microbial and hazard analysis. It was found that quality differed according to the manufacturers of Rosogolla. The chemical analysis score implies that moisture, fat, protein, total sugar and ash content varied significantly $(p<0.05)$ among four different types of Rosogolla. The mineral content i.e. $\mathrm{Na}, \mathrm{K}, \mathrm{Mn}, \mathrm{Fe}, \mathrm{Zn}$ and $\mathrm{Ca}$ in all samples were statistically significant ( $p<0.05$ ). The toxic heavy metals such as $\mathrm{As}, \mathrm{Cr}, \mathrm{Hg}$ and $\mathrm{Pb}$ were not detected in all sample. It was found that the standard plate count in all sample were higher than the maximum permissible level of Bangladesh Standard and Testing Institute (BSTI) standard except $R_{2}$ sample. Total coliform and total fungal count in all samples also found in unsatisfactory level. About 50\% sample contained Salmonella and Staphylococcus aureus which may be a hazard to consumer as they are pathogenic bacteria.
\end{abstract}

Keywords: Sweetmeat, proximate composition, safety, Pathogenic bacteria, Heavy metal.

\section{Introduction}

Sweetmeats are very popular food item in Bangladesh. The sweetmeat is very delicious, wholesome, nutritious and famous food in Bangladesh [1,2]. Different types of sweetmeats are available in Bangladesh, such as Rosogolla, Ros Malai, Malai Chop and Shor Puria, Pora Bari Cham cham, Muktagachhar Monda, Bogra Doi, Chhana Mukhi, Lal Mohan, Kalojam, Paera, Kacha Chhana, Buffalo curd, Jilepi, Sondesh, Balushai, Laddu, Pitha, Rabri, Khirsha and many others. Tangail city is famous for sweetmeats. Sweetmeats are the inseparable part of Bangladeshi cultural and religious festivals. Besides the festivals, the sweetmeats also make a part of daily intake and rap round with entire life of Bangladeshi people. Sweetmeats are generally prepared from cow's milk, buffalo milk, and mixture of cow and buffalo milk. Chhana is the main ingredient of most of the popular sweetmeats available in Bangladesh. Chhana is good source of milk protein, fat and minerals. But these products are extremely vulnerable to contamination with spoilage and pathogenic organisms if subjected to adverted and inadvertent abuse during their production and processing. More than 200 foodborne illnesses are now recognized and most of them required specific laboratory diagnosis [3]. The toxicity induced by excessive levels of some of the heavy metals i.e. Arsenic (As), chromium $(\mathrm{Cr})$, lead $(\mathrm{Pb})$ and mercury $(\mathrm{Hg})$, are well known [4]. The microbiological safety and quality of foods are directly related to identify the number of microorganism present in the products such as bacteria, yeast, mold, pathogens (i.e. salmonella, staphylococcus spp) and total coliforms. Among Coliforms, Escherichia coli have attracted much attention recently as a potential pathogen since several strains of enteropathogenic E. coli have been isolated from raw and pasteurized milk and milk products suspected to be associated with outbreak of gastroenteritis and food poisoning in human being [5]. Considering the public health importance of sweetmeat consumers, it is needless to say that the product should be prepared under strict hygienic condition. There are some specific standards for the sweetmeat constituents prepared by the Bangladesh Standard and Testing Institute. Besides, long storage, poor maintenance can lead to microbial contamination. Use of contaminated raw materials, unhygienic equipments and contaminated water will increase the proneness of sweets to be hazardous. The chhana based sweetmeats are generally prepared by adopting traditional methods. Although Bangladeshi people consume huge amount of sweetmeats but scanty literature about sweetmeat is available. Thus the study work has been undertaken with a view- to assess the nutritional and microbiological quality and identifying heavy metals such as $\mathrm{Pb}, \mathrm{Cr}, \mathrm{AS}$, and $\mathrm{Hg}$ in the sweetmeat and comparing with Bangladesh standard (BSTI standard). 


\subsection{Sample collection}

\section{Materials And Methods}

The sweetmeat selected for the study was Rosogolla available in Dhaka and Tangail regions of Bangladesh. Sweetmeats were collected from a branded shop and a non-branded shop in Dhaka city and a branded and non-branded shop in Tangail district area. Rosogolla sample collected from a branded shop in Tangai city is designated as $R_{1}$ sample whereas sample collected from a non branded sample in Tangail city is $R_{2}$ sample. On the other hand Rosogolla sample collected from a branded shop in Dhaka city leveled as $R_{3}$ and sample from non branded shop as $\mathrm{R}_{4}$.

\subsection{Place of Experiment}

The sample analyses were conducted in the laboratory of Food Technology and Nutritional Science Department, Mawlana Bhashani Science and Technology University, Tangail and in the Institute of Food Science and Technology (IFST), Bangladesh Council of Science and Industrial Research (BCSIR), Dhaka.

\subsection{Sample preparation}

After collection, the samples were kept in the refrigerator until further experimental work. Samples were slightly prepared by mashing and subjected to chemical, microbial and hazard analysis.

\subsection{Analysis of the samples}

Proximate analysis (moisture, fat, protein, total sugar and ash) tests, microbiological (total viable bacteria, total fungi, coliform, E. coli, Salmonella) analysis and analysis for minerals ( $\mathrm{Na}, \mathrm{K}, \mathrm{Ca}, \mathrm{Zn}, \mathrm{Fe}, \mathrm{Mn}$ ) and heavy metals $(\mathrm{Cr}, \mathrm{Pb}, \mathrm{As}, \mathrm{Hg})$ were conducted to monitor the quality of Rosogolla samples. Estimation of moisture was done by oven drying method [6]. Estimation of ash, protein and fat was done by using dry ash, Kjeldahl and Soxhlet apparatus methods respectively [6]. Total sugar content was determined by AOAC (2000) official method [7]. Coliform was determined by MPN-confirmation test. Total faecal coliform E.coli was determined by two successive tests, MPN-Presumptive Tests and MPN-Confirmed tests. For isolation of salmonella, Lactose Broth (LB), Selenite Broth (SB), Bismuth Sulphite Agar (BSA) and Triple Sugar Iron Agar (TSI) were used. Standard Plate Count (SPC) method was used for quantitative analysis of bacterial load. Potato Dextrose Agar (PDA) medium was used to determine the total fungal count by spread plate method [8]. The microbial counts were expressed as colony forming unit (cfu/g). Minerals were determined by Atomic Absorption Spectrophotometer (AAS-700, SHIMADZU) after appropriate wet digestion of the samples. For determination of chromium and lead Atomic Absorption Spectrophotometer was used. HVG-1 Hydride Vapor Generator and atomic absorption spectrophotometer were used for quantification of As. MVU-1A Mercury Vaporizer Unit and atomic absorption spectrophotometer were used for quantification of $\mathrm{Hg}$.

\subsection{Statistical analysis}

Data collected from different parameters were subjected to statistical analysis. One way Anova was performed for identifying the significant (at $5 \%$ level or $1 \%$ level) level by Statistical Package for the Social Sciences (SPSS, 20).

\subsection{Proximate composition of Rosogolla \\ 3.1.1 Moisture content}

\section{Results And Discussion}

There were significant differences $(p<0.05)$ in the moisture content of Rosogolla collected from different sources as shown in table-1. The moisture content of Rosogolla ranged from 31.88 to $47.13 \%$. The average moisture content in Sweetmeat (Rosogolla) samples $R_{1}, R_{2}, R_{3}$ and $R_{4}$ were 47.13, 34.63, 31.88 and $33.55 \%$ respectively. BSTI standard is maximum 55\% moisture. Higher moisture content was noticed in sample $\mathrm{R}_{1}$. The higher moisture content are related to good quality flavor and texture of Rosogolla. Tewari and Sachdeva (1991) observed good flavor in the Rosogolla chhana containing 62.5-63.5\% moisture [9]. Gupta et al. (1993) and Ravichandra et al. (1997) reported that the overall textural quality of Rosogolla was significantly correlated with its moisture content $[10,11]$.

\subsubsection{Fat content}

Fat content of Rosogolla samples is represented in Table 1. The fat content of Rosogolla ranged from $2.72 \%$ to $14.41 \%$.The amount of mean fat content of $R_{1}, R_{2}, R_{3}$ and $R_{4}$ samples were $2.72,14.41,3.68$ and $3.50 \%$ respectively. As BSTI standard, a minimum of 5\% milk fat is specified. Only Rosogolla sample $\mathrm{R}_{2}$ assured the requirement for milk fat. Such finding might be owing to use of low fat milk or skimming of fat from whole milk before preparing chhana and Rosogolla. Bhattacharya and Raj (1980) reported that use of high 
fat milk leads to Rosogolla having higher fat content [12]; increased fat content in product tends to soften the body and improve the texture of resultant product.

Table 1: Proximate analysis of market Rosogolla collected from Dhaka and Tangail regions

\begin{tabular}{|l|l|l|l|l|l|l|}
\hline \multirow{2}{*}{ Parameter } & BSTI & \multicolumn{4}{l|}{ Composition of Rosogolla samples } & \multicolumn{2}{l|}{$\begin{array}{l}\text { Level of } \\
\text { standard }\end{array}$} & $\mathrm{R}_{1}$ & $\mathrm{R}_{2}$ & $\mathrm{R}_{3}$ & $\mathrm{R}_{4}$ & \\
\hline Moisture (\%) & $55(\max )$ & $47.13 \pm 0.33$ & $34.63 \pm 0.55$ & $31.88 \pm 0.33$ & $33.55 \pm 0.39$ & $* *$ \\
\hline Fat (\%) & $5(\mathrm{~min})$ & $2.72 \pm 0.10$ & $14.41 \pm 6.43$ & $3.68 \pm 0.12$ & $3.50 \pm 0.05$ & $\mathrm{NS}$ \\
\hline Protein (\%) & $5(\mathrm{~min})$ & $3.91 \pm 0.12$ & $5.06 \pm 0.07$ & $5.13 \pm 0.06$ & $4.85 \pm 0.09$ & $* *$ \\
\hline Total Sugar (\%) & $50(\max )$ & $50.74 \pm 0.49$ & $48.00 \pm 0.21$ & $49.36 \pm 0.23$ & $49.33 \pm 0.21$ & $* *$ \\
\hline Ash (\%) & $0.9(\max )$ & $0.84 \pm 0.014$ & $0.82 \pm 0.007$ & $0.80 \pm 0.006$ & $0.75 \pm 0.005$ & $* *$ \\
\hline
\end{tabular}

Data are expressed as mean \pm standard deviation, $* *$ means significance level $(p<0.01), *$ means significance level $(p<0.05)$, NS means Not-significant.

\subsubsection{Protein content}

Tables 1 represent the protein content of Rosogolla samples. The protein content of Rosogolla ranged from 3.91 to $5.13 \%$. The protein content was $3.91,5.06,5.13$ and $4.85 \%$ for $R_{1}, R_{2}, R_{3}$ and $R_{4}$ respectively. When comparing the four Rosogolla samples, the protein content was significantly $(p<0.05)$ different. Although $R_{3}$ sample contained higher percentage of protein, $R_{3}$ and $R_{2}$ sample contained protein content which was well above the minimum level prescribed by BSTI. The other two Rosogolla samples $\left(\mathrm{R}_{1}\right.$ and $\left.\mathrm{R}_{4}\right)$ contained protein content which was low as BSTI standard permitted. Higher protein content increases the firmness and sponginess of Rosogolla. A protein content of $6.62 \%$ has been reported in spongy Rosogolla [13].

\subsubsection{Total sugar content}

Total sugar content of Rosogolla samples is presented in Table 1. Total sugar content ranged from 48.00 to $50.74 \%$; the total sugar content was $50.74,48.00$, and 49.36 and $49.33 \%$ respectively for samples $R_{1}$, $R_{2}, R_{3}$ and $R_{4}$. The difference in the total sugar content between Rosogolla samples was found to be statistically significant $(p<0.05)$. Market sample of Rosogolla may have adulteration by using high intense sweetener such as saccharine, aspartame, acesulfame-K etc but it was observed that desired level of total sugar was kept in Rosogolla samples. As per BSTI specification, a maximum total sugar content of $50.0 \%$ is permitted in Rosogolla.

\subsubsection{Ash content}

There were significant differences $(p<0.05)$ in the ash content of Rosogolla collected from different sources as represented in Table 1 . The ash content was $0.84,0.82,0.80$ and $0.75 \%$ for Rosogolla samples $R_{1}, R_{2}$, $R_{3}$ and $R_{4}$ respectively. BSTI standard is maximum $0.9 \%$ ash content. Katra and Bhargave (1990) reported that higher ash and total carbohydrate in Rosogolla decreased its sponginess [14]. All the Rosogolla samples had ash content that complied with the BSTI standard; however, $\mathrm{R}_{1}$ sample had higher level of ash as compared to others.

\subsection{Microbial quality of Rosogolla \\ 3.2.1 Standard plate count}

The Standard plate count (SPC) of Rosogolla samples are shown in Table 3.The SPC ranged from 3.89 $\times 10^{2}$ to $4.6 \times 10^{7} \mathrm{cfu} / \mathrm{g}$. The SPC for samples $\mathrm{R}_{1}, \mathrm{R}_{2}, \mathrm{R}_{3}$ and $\mathrm{R}_{4}$ were $4.6 \times 10^{7}, 3.89 \times 10^{2}, 1.5 \times 10^{3}$ and $2.49 \times 10^{7}$ cfu/g respectively. The BSTI standard specifies a maximum limit of $500 \mathrm{cfu} / \mathrm{g}$ in sweetmeat. The SPC of $\mathrm{R}_{1}$ and $\mathrm{R}_{4}$ samples were out of BSTI standard hence were considered unsatisfactory for consumption. SPC of $\mathrm{R}_{2}$ sample conformed to the BSTI standard.

\subsubsection{Total coliform count}

The coliform count in Rosogolla samples are depicted in Table 3.Total coliform ranged from $0.25 \times 10^{2}$, to $2.5 \times 10^{2}, \mathrm{MPN} / \mathrm{g}$. Total coliform found in samples $\mathrm{R}_{1}, \mathrm{R}_{2}, \mathrm{R}_{3}$ and $\mathrm{R}_{4}$ were $2.50 \times 10^{2}, 2.32 \times 10^{2}, 0.25 \times 10^{2}$ and $2.50 \times 10^{2} \mathrm{MPN} / \mathrm{g}$ respectively. BSTI standard dictates absence of coliform in sweetmeat. Among coliforms, $E$. coli has attracted much attention as a potential pathogen since several strains of enteropathogenic E.coli have been isolated from milk products suspected to be associated with outbreak of gastroenteritis and food poisoning in human being [5]. E. coli frequently contaminates food and it is an indicator of fecal contamination [16, 17]. Presence of $E$. coli in milk products indicates the presence of enteropathogenic microorganisms, which constitute a public health hazard. Enteropathogenic E. coli can cause severe diarrhea and vomiting in infants, and young children [18]. 
Table 3: Microbial quality of Rosogolla collected from Dhaka and Tangail region.

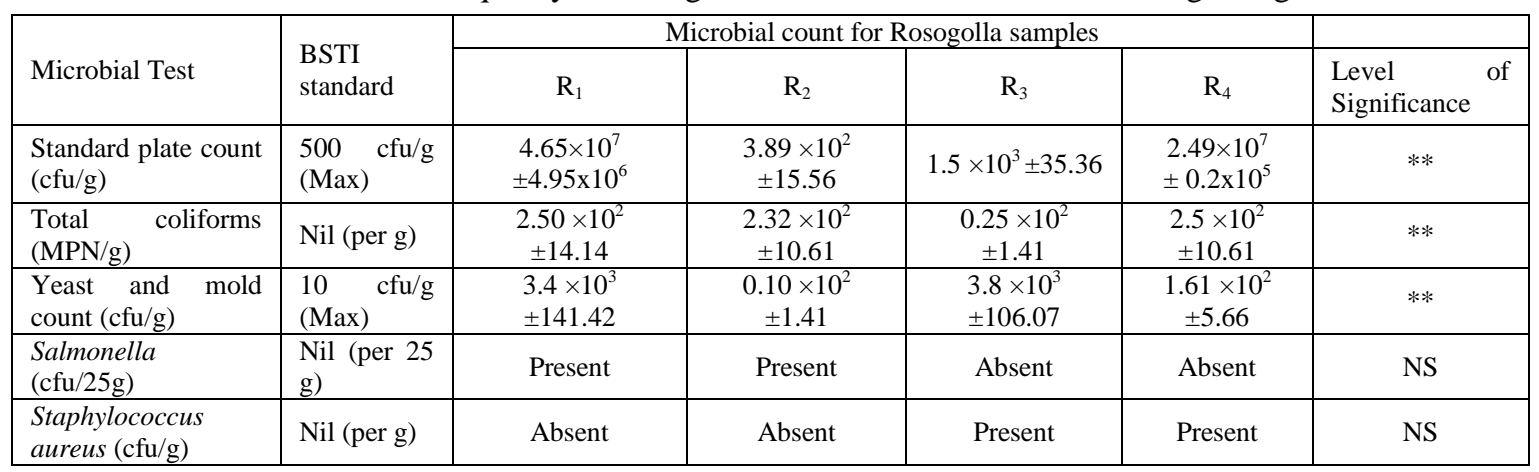

Data are expressed as mean \pm standard deviation, ** means significance level $(p<0.01)$, * means significance level $(p<0.05)$, NS means Not Significant.

\subsubsection{Yeast and Mold count}

The yeast and mold (Y\&M) count of Rosogolla samples are shown in Table-3. The Y\&M count ranged from $0.10 \times 10^{2}$ to $3.8 \times 10^{3} \mathrm{cfu} / \mathrm{g}$. The $\mathrm{Y} \& \mathrm{M}$ count of samples $\mathrm{R}_{1}, \mathrm{R}_{2}, \mathrm{R}_{3}$ and $\mathrm{R}_{4}$ were $3.4 \times 10^{3}, 0.10 \times 10^{2}, 3.8 \times 10^{3}$ and $1.61 \times 10^{2} \mathrm{cfu} / \mathrm{g}$ respectively. BSTI standard specified maximum of $10 \mathrm{cfu} / \mathrm{g}$ in sweetmeat. The Y\&M count of $R_{1}, R_{3}$ and $R_{4}$ samples were higher than BSTI limit. Only sample $R_{2}$ could meet the BSTI standard for $Y \& M$ count. Indigenous sweet based product like Gulabjamun, Rosogolla are highly susceptible to variety of microorganism because of high nutritive value and complex chemical composition [19]. Kamat and Sulebele (1974) studied the microbiological quality of milk based sweets in twin cities of Hyderabad and Secunderabad and observed that $90 \%$ of peda, $75 \%$ of kalakand and $100 \%$ of Rosagollas were contaminated with yeast and molds [20].

\subsubsection{Salmonella}

The analysis for Salmonella in Rosogolla samples are shown in Table 3. Salmonella was found in $\mathrm{R}_{1}$ and $\mathrm{R}_{2}$ samples, while it was absent in $25 \mathrm{~g}$ of samples $\mathrm{R}_{3}$ and $\mathrm{R}_{4}$. BSTI standard demands absence of Salmonella in sweetmeat per $\mathrm{g}$ sample. Presence of such pathogenic bacteria can be a causative factor for disease like salmonellosis [21].

\subsubsection{Staphylococcus aureus}

The result of analysis for Staphylococcus aureus in Rosogolla samples is depicted in Table 3. Staphylococcus aureus was detected in samples $\mathrm{R}_{3}$ and $\mathrm{R}_{4}$, while it was absent in $1 \mathrm{~g}$ samples $\mathrm{R}_{1}$ and $\mathrm{R}_{2}$. BSTI standard specified absence of Staphylococcus aureus in per gram of sweetmeat sample. Enterotoxins produced by Staphylococcus aureus is harmful (i.e. causes food poisoning) to human health. About $50 \%$ of such organisms are able to produce enterotoxins [22]. Staphylococcus aureus had been isolated from Khoa samples $[23,24]$. Illness through $S$. aureus range from minor skin infection such as pimples, boils, cellulites, toxic shock syndrome, impetigo, and abscesses to life threatening disease such as pneumonia, meningitis, endocarditis, and septicemia $[23,19]$.

\subsection{Hazard analysis of Rosogolla Sample 3.3.1 Minerals}

The mineral content of Rosogolla samples are depicted in table 2. The sodium content of Rosogolla ranged from 37.46 to $49.64 \mathrm{mg}$ per $100 \mathrm{~g}$ product. The Na content of samples $R_{1}, R_{2}, R_{3}$ and $R_{4}$ were 42.15 , 44.11, 49.64 and $37.46 \mathrm{mg} / 100 \mathrm{~g}$ product respectively. Highest percentage of $\mathrm{Na}$ was noted in sample $\mathrm{R}_{3}$. The amount of potassium in samples $R_{1}, R_{2}, R_{3}$ and $R_{4}$ were $25.21,12.20,15.22$ and $17.30 \mathrm{mg} / 100 \mathrm{~g}$ product respectively. There was a large variation with regard to $\mathrm{K}$ content in Rosogolla samples; the highest and least content of $\mathrm{K}$ was found in $\mathrm{R}_{1}$ and $\mathrm{R}_{2}$ sample respectively. Manganese ranged from 0.06 to $0.13 \mathrm{mg} / 100 \mathrm{~g}$ product. The $\mathrm{Mn}$ content in samples $\mathrm{R}_{1}, \mathrm{R}_{2}, \mathrm{R}_{3}$ and $\mathrm{R}_{4}$ were $0.13,0.12,0.07$ and $0.06 \mathrm{mg} / 100 \mathrm{~g}$ of product respectively. The Fe content of samples $R_{1}, R_{2}, R_{3}$ and $R_{4}$ were 5.59, 4.46, 6.22 and $4.80 \mathrm{mg} / 100 \mathrm{~g}$ of product respectively. Highest content of Fe was associated with sample $R_{3}$. Zinc ranged from 1.19 to $1.63 \mathrm{mg} / 100 \mathrm{~g}$ of product. The Ca content of samples $\mathrm{R}_{1}, \mathrm{R}_{2}, \mathrm{R}_{3}$ and $\mathrm{R}_{4}$ were $62.48,67.14,56.22$ and $45.10 \mathrm{mg} / 100 \mathrm{~g}$ of product respectively. The Rosogolla is therefore a nutritious food being rich in mineral content. A sweet products supplies the most essential elements like proteins, vitamin-B, calcium and phosphorus along with numerous other essential major and minor substances [15]. It was found that almost all of the Rosogolla samples showed satisfactory level of mineral content. 
Table 2: Comparison of minerals and heavy metal content of Rosogolla collected from Dhaka and Tangail region.

\begin{tabular}{|c|c|c|c|c|c|c|}
\hline \multirow{2}{*}{\multicolumn{2}{|c|}{ Parameters }} & \multicolumn{4}{|c|}{ Mineral and heavy metal content of Rosogolla } & \multirow{2}{*}{$\begin{array}{l}\text { Level of } \\
\text { Significance }\end{array}$} \\
\hline & & $\mathrm{R}_{1}$ & $\mathrm{R}_{2}$ & $\mathrm{R}_{3}$ & $\mathrm{R}_{4}$ & \\
\hline \multirow{6}{*}{ Minerals } & $\mathbf{N a}(\mathrm{mg} / 100 \mathrm{~g})$ & $42.15 \pm 0.33$ & $44.11 \pm 4.22$ & $49.64 \pm 2.62$ & $37.46 \pm 1.88$ & $*$ \\
\hline & $\mathbf{K}(\mathrm{mg} / 100 \mathrm{~g})$ & $25.21 \pm 0.20$ & $12.20 \pm 1.17$ & $15.22 \pm 0.81$ & $17.30 \pm 0.83$ & $* *$ \\
\hline & Mn $(\mathrm{mg} / 100 \mathrm{~g})$ & $0.13 \pm 0.010$ & $0.12 \pm 0.012$ & $0.07 \pm 0.004$ & $0.06 \pm 0.003$ & *** \\
\hline & Fe $(\mathrm{mg} / 100 \mathrm{~g})$ & $5.59 \pm 0.04$ & $4.46 \pm 0.42$ & $6.22 \pm 0.17$ & $4.80 \pm 0.23$ & $* *$ \\
\hline & $\mathbf{Z n}(\mathrm{mg} / 100 \mathrm{~g})$ & $1.25 \pm 0.03$ & $1.21 \pm 0.11$ & $1.19 \pm 0.06$ & $1.63 \pm 0.08$ & *** \\
\hline & Ca $(\mathrm{mg} / 100 \mathrm{~g})$ & $62.48 \pm 0.49$ & $67.14 \pm 6.42$ & $56.22 \pm 2.98$ & $45.10 \pm 2.19$ & $* *$ \\
\hline Heavy metals & $\mathrm{As}, \mathrm{Cr}, \mathrm{Hg}, \mathrm{Pb}$ & Not Detected & Not Detected & Not Detected & Not Detected & $* *$ \\
\hline
\end{tabular}

Data are expressed as mean \pm standard deviation, ** means significance level $(p<0.01), *$ means significance level $(p<0.05), \mathrm{NS}=$ Non-significant.

\subsubsection{Heavy metals}

Table 2 shows the heavy metals contents of Rosogolla samples. Harmful Heavy metals like As, $\mathrm{Cr}, \mathrm{Hg}$ and $\mathrm{Pb}$ were not detected in the Rosogolla samples. This implies that contamination with heavy metals did not take place during processing nor did it come through use of substandard quality raw materials. Milk and dairy products have a greater chance to contaminate from environmental conditions, manufacturing process. The toxicity induced by excessive levels of some of these elements, such as Arsenic (As), chromium $(\mathrm{Cr}), \mathrm{lead}(\mathrm{Pb})$ and mercury $(\mathrm{Hg})$, are well known [4].

\section{Conclusion}

The assessment of nutritional quality of Rosogolla found in Dhaka and Tangail region revealed compliance with the BSTI standard for such sweetmeat product. In comparison with BSTI standard moisture and total sugar content in all samples was satisfactory level. The fat percentage in all samples also in acceptable level except sample $\mathrm{R}_{1}$. About $50 \%$ sample contained protein that fulfill BSTI standard and the entire sample contained ash content which did not fulfill BSTI standard. Toxic heavy metals such as $\mathrm{Pd}, \mathrm{Cr}, \mathrm{As}$ and $\mathrm{Hg}$ were absent in the tested rosogolla sample. With regard to the microbial quality of market rosogolla, the high bacterial count and presence of coliforms in large numbers points to the unhygienic practices during product manufacture and handling. The presence of pathogenic bacteria i.e. salmonella and Staphylococcus aureus in 50\% of the market samples also poses a threat to the human health.

\section{References}

[1]. A.K.M. Mannan, M.S. Hossian, and M.N. Islam, Standard and Standardization of Sweetmeats. Standard of traditionally made Chhana and Rosogolla, Bangladesh Agriculture University (BAU), Res. Prog. 8, 1994, 410-413.

[2]. M.Z. Islam, S.M.R. Rahman, M.M. Alam, M.Y. Ali, and A.K.M.A Manna, Manufacture of rosomalai and its quality attribute: An indigenous milk sweetmeat of Bangladesh, Pakistan J. Nutr, 2, 2003, 300-304.

[3]. D.N, Prasad, Hygenic and safety aspects of dairy products, Indian Dairyman, 50, 1998, 12-18

[4]. J.M. Llobet, A. Domingo, A. Bocio, A. Casas, and L. Muller, Human exposure to dioxins through the diet in Catalonia, Spain: Carcinogenic and non-carcinogenic risks, Chemosphere, 50. 2003, 1193-1200

[5]. R.S. Sing, and B. Ranganathan, Incidence and distribution of Escherichia coli in dairy products, Indian J. Dairy Sci, 31, 1978, 1-8

[6]. AOAC, Official methods of Analysis of AOAC, International, Washington, DC: Association of Official Analytical Chemist., 16, $1985,15-46$

[7]. AOAC, Official methods of Analysis of AOAC, International, Washington, DC: Association of Official Analytical Chemist., 16, 2000, 15-46.

[8]. ICMSF, Microorganisms in food. Microbial ecology of food commodities, 6, 1988, 615-616

[9]. B.D. Tewari, and S. Sachdeva, Effect of processing variables on quality of spread prepared from chhana, Indian J. Dairy Science, 44, 1991, 375-379

[10]. S.K. Gupta, A.A. Patel, G. R. Patil, H. K. Desai, and B. C. Ghosh, Texture studies on selected Indian dairy products: composition, texture relationships, Int. Dairy Fedn, 2, 1993, 176-182.

[11]. M.N. Ravichandra, H. N. Mishra, and H. Das, Optimization of process parameters for the production of rosogolla from cow milk, J. Food Sci. \&Technol (Mysore), 34.1997, 46-49

[12]. D.C. Bhattacharya, and D. Raj, Studies on the production of Rosogolla. Part-I: traditional method, Indian J. Dairy Sci, 33, 1980, $237-243$

[13]. A. Sur, P. K Ghatak, and A. K. Bandhyopadhyay, A study on the quality of rosogolla made from buffalo milk, J. Dairying Foods \& Home Science, 19, 2000, 61-63

[14]. R.V. Katra, and V.N. Bharagava, Production of rosogolla from cow milk containing different levels of soy milk, Asian J. Dairy Res, 9, 1990, 175-180

[15]. N. Karthikeyan, and B. Dhanalakshmi, Hygienic quality of Indian sweet milk products from different sources, Bangladesh J. Micro, 27, 2010, 32-37

[16]. L.R. Diliello, Methods in Food and Dairy Microbiology. AVI Publishing Co. Inc., Westport, CT, USA, 1982, 39

[17]. A.H. Soomro, M.A. Arain, M. Khaskheli, and B. Bhutto, Isolation of Escherichia coli from raw milk and milkproducts in relation to public health sold under market condition at Tandojam, Pak. J. Nutr., 1, 2002, 151-152.

[18]. N. Benkerroum, Y.E.I. Bouhal, A. Attar, and A. Marhaben, Occurrence of Shiga toxin-producing E. coli 0157:H7 in selected diary and meat products marketed in the city of Rabat, Morocco. J. Food, 76, 2004, 1234-1237. 
[19]. A.H. Soomro, M.A. Arain, M. Khaskheli, B. Bhutto, and A. Q Memon, Isolation of Staphylococcus aureus from milk products sold at sweet meat shops of Hyderabad, Online J. Biological Sci, 3, 2003, 91-94.

[20]. M.Y. Kamat, and G.A. Sulebele, Microbiological quality of pedha, J. Food. Sci.Technol, 111, 1974, 50-55

[21]. J. B. George, Basic Food Microbiology. Abridged Textbook Edition. AVI Publishing Company, INC. Westport, Connecticut, 1981

[22]. D. N. Payne, and J. M Wood, The incidence of enterotoxin production in strains of Staphylococcus aureus isolated from food, $J$. Applied Bacterio, 18, 1974, 319-325

[23]. T. Masud, H.I. Ather, C. M Azhar, and S. M. Amim, Microbiological studies on indigenous dahi with special reference to public health, Aust. J. Dairy Technol, 8, 1988, 8-13

[24]. J. S. Grewal, and R. P Tiwari, Microbiological quality of rasmalai, J. Food Sci. \&Technology, Mysore, 27,1990, 178-179 